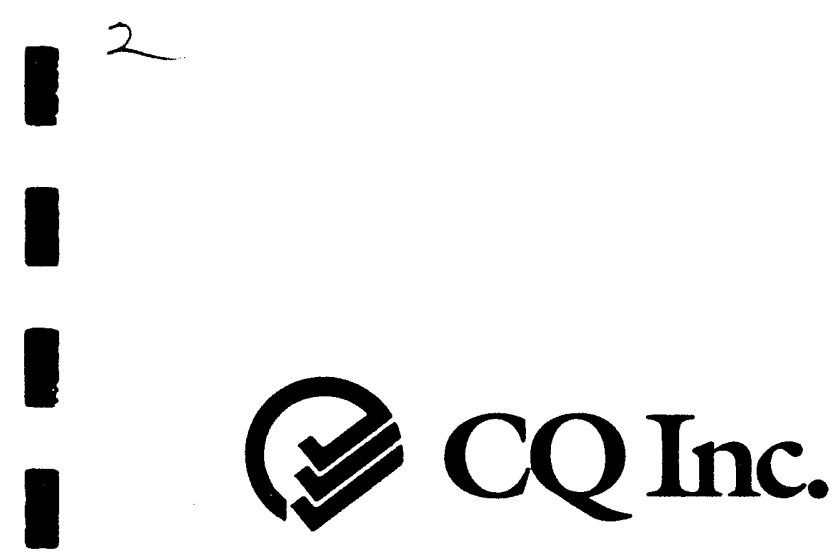

Technical Progress Report No. 5

Development of a Coal Quality Expert

to

\author{
U.S. Department of Energy \\ Pittsburgh Energy Technology \\ Center \\ Pittsburgh, Pennsylvania \\ DE-FC-22-90PC89663
}


Technical Progress Report No. 5

\title{
Development of a Coal Quality Expert
}

\author{
U.S. Department of Energy \\ Pittsburgh Energy Technology Center \\ Pittsburgh, Pennsylvania
}

DE-FC22-90PC89663

August 30, 1991

\section{DISCLAIMER}

This report was prepared as an account of work sponsored by an agency of the United States Government. Neither the United States Government nor any agency thereof, nor any of their employees, makes any watranty, express or implied, or assumes any legal liability or responsibility for the accuracy, completeness, or usefulness of any information, apparatus, product, or process disclosed, or represents that its use would not infringe privately owned rights. Reference herein to any specific commercial product, process, or service by trade name, trademark. manufacturer, or otherwise does not necessarily constitute or imply its endorsement, recommendation, or favoring by the United States Government or any agency thereof. The views and opinions of authors expressed herein do not necessarily state or reflect those of the United States Government or any agency thereof.

$C Q$ Inc.

One Quality Center

Post Office Box 280

Homer City, Pennsylvania 15748

(412) 479-3503 
This is the fifth Technical Progress Report, describing work performed under DOE Contract No. DE-FC22-

90PC89663, "Development of a Coal Quality Expert." The contract is a Cooperative Agreement between the U.S. Department of Energy, CQ Inc., and Combustion Engineering, Inc. This report covers the period from April 1 through June 30, 1991. Four companies and seven host utilities have teamed with $C Q$ Inc. and C-E to perform the work on this project. The work falls under DOE's Clean Coal Technology Program category of "Advanced Coal Cleaning." The 45-month project will provide the utility industry with a PC expert system to confidently and inexpensively evaluate the potential for coal cleaning, blending, and switching options to reduce emissions while producing lowest cost electricity. Specifically, this project will:

- Enhance the existing Coal Quality Information System (CQIS) database and Coal Quality Impact Model (CQIM) to allow confident assessment of the effects of cleaning on specific boiler cost and performance.

- Develop and validate a methodology, Coal Quality Expert (CQE) which allows accurate and detailed predictions of coal quality impacts on total power plant capital cost, operating cost, and performance based upon inputs from inexpensive bench-scale tests.

The project consists of the following seven tasks:

- Task 1 - Project Management

- Task 2 - Coal Cleanability Characterization

- Task 3 - Pilot-Scale Combustion Testing

- Task 4 - Utility Boiler Field Testing

- Task 5 - CQIM Completion and Development of CQE Specification

- $\quad$ Task 6 - Develop CQE

- Task 7 - CQE Workstation Testing and Validation 
WORK PERFORMED

Task 2 - Coal Cleanability Characterization
During the past quarter, Tasks $2,3,4$, and 5 were active. Data reduction and report preparation continued for the coal cleanability characterization studies performed on the PSO Northeastern and MPC Watson coals. Pilot-scale combustion tests with the PSO Northeastern coals were completed, and tests were initiated with the MPC Watson coals. Field combustion tests with the baseline coal were conducted at Northern States Power Company's Allen S. King Station Unit No. 1 (NSP King 1); data reduction and interpretation continued for the MPC Watson field tests. Task 5 activities were directed at overall CQE program definition, investigation of basic functionality software needs/sources, Beta testing of the Acid Rain Advisor (ARA), and definition and planning for algorithm development.

A test report for the coal cleanability characterization studies performed on the Croweburg Seam coal - burned as part of the blend during the PSO Northeastern field tests - is in preparation, to be submitted in July.

Characterization of the Watson coals was completed, and analysis of the data continues. Impurities liberation studies were completed for both the baseline (Jader Illinois blend) and alternate (Island Creek Kentucky No. 11 Seam) coals. Preliminary evaluation of the data indicates modest liberation of mineral matter and pyritic sulfur when crushing the raw coal to the finer topsizes (i.e., 28 and 100 mesh). Cleaning of the Kentucky No. 11 Seam coal did result in significant reductions of the following trace elements: barium, chromium, fluorine, lead, nickel, and zinc.

Initial arrangements wcre made to collect coal samples for characterization studies as part of the NSP King test program. Originally, two coals from the Powder River Basin were to be obtained for coal cleanability evaluations at $\mathrm{CQ}$ Inc. However, it was decided that the CQE program would be better served by performing raw coal characterizations on a greater number of Western coals, rather than cleanability evaluations of only two. Up to eight coals from Wyoming and Montana will be characterized during the third and fourth quarters of 1991, significantly increasing the Western coal database of CQIS. 
Task 3 - Pilot-Scale Combustion Testing

Bench-Scale Testing

Pilot-Scale Testing
Task 3 provides detailed characterization of fuel properties of the test coals and in-depth evaluation of their performance characteristics under controlled pilot-scale combustion testing. Results from this task provide fundamental information required to develop the improved algorithms for the CQE. Both bench-scale fuel characterization and test furnace performance evaluations are being performed under this task.

During the past quarter, pilot-scale studies for the PSO Northeastern test program were completed at CE's Fireside Performance Test Facility (FPTF) with the testing of the $70 \%$ Wyoming/30\% Oklahoma (cleaned) blend. Pilot-scale testing of the Watson coals began in May. Bench-scale testing continued at $\mathrm{CE}$ and the University of North Dakota's Energy and Environmental Research Center (EERC).

ASTM standard and specialty tests (flammability index, weak acid leaching, TGA char reactivity, and BET char surface areas) and Drop Tube Furnace System-1 testing were performed on the $70 \% \mathrm{WY} / 30 \% \mathrm{OK}$ (cleaned) blend; DTFS-1 testing was also initiated on both Watson coals. DTFS-1 combustion kinetic parameters, including activation energies, frequency factors, swelling factors, and mercury densities, were derived for the $100 \%$ Wyoming and Oklahoma coals.

Characterization of coal, deposits, and entrained ash was completed at the EERC for a suite of samples collected during the FPTF testing of $100 \% \mathrm{WY}$ and $70 \% \mathrm{WY} / 30 \%$ OK blend. Types of analyses performed included chemical fractionation and computer-controlled scanning electron microscopy (CCSEM) for the coals, and x-ray fluorescence, $\mathrm{x}$-ray diffraction, Malvern sizing, loss on ignition, and scanning electron microscopy point count (SEMPC) for the entrained as' and deposits. Coal and ash deposits from FPTF testing of the $90 \% \mathrm{WY} / 10 \%$ OK blend and $70 \%$ $\mathrm{WY} / 30 \%$ OK (cleaned) will be characterized at the EERC during the third quarter of 1991.

The FPTF is being used to evaluate the effects of coal properties on pulverization, ash deposition, combustion, erosion, and emissions. Testing of all the PSO coals was completed and the final analyses were initiated. Operating 
conditions and heat flux recoveries for these tests are summarized in Table 1 . The percent heat flux recovery when soot was blown on panel 1 of the furnace, coupled with visual observations were used to establish the critical thermal furnace conditions for each of the coals:

$\begin{array}{llll}\text { Coal } & \text { Load (MBfu/hr) } & \text { Gas Temp (' F) } & \text { NHI/PA } \\ \text { 100\% WY } & 3.3 & 2825-2850 & 1.65 \\ 90 \% \text { WY / 10\% OK } & 3.7 & 2925-2950 & 1.85 \\ 70 \% \text { WY / 30\% OK } & 3.2 & 2800-2825 & 1.60 \\ 70 \% \text { WY / 30\% OK(CL) } & 3.8 & 2950-2975 & 1.90\end{array}$

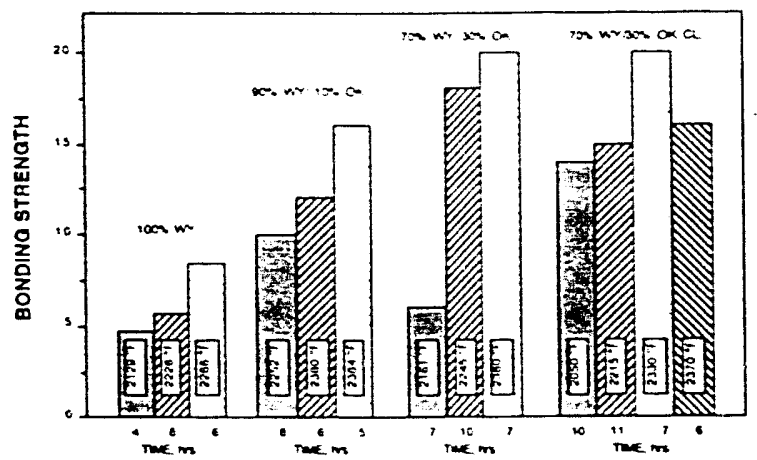

Typical bonding strengths measured from simulated fouling tube deposits in the FPTF are summarized in the adjacent figure. The strength to which deposits are bonded to super heater surfaces is largely a function of both the local gas temperature and the time required to form a deposit which was 2.5 to 3 inches in length. Past experience has shown that deposits which possess bonding strengths of 15 or higher are non-removable by normal soot blowing techniques.

The $100 \%$ Wyoming coal formed deposits which were significantly more removable over a wide range of loads compared to the other PSO blends tested. The general trend tested showed that fouling deposit bonding strength increased with the amount of Oklahoma raw coal in the blend.

The critical thermal conditions indicated that the $70 \%$ $\mathrm{WY} / 30 \%$ OK cleaned coal blend was able to be fired at the highest firing rate without limiting the heat adsorption in the lower furnace; however, the increased temperature and buildup rates resulting in the upper furnace would cause fouling deposit formations which would be non-removable with soot blowers, thus limiting boiler performance.

Erosion rates found for the $90 \% \mathrm{WY} / 10 \% \mathrm{OK}$ and the $70 \%$ WY $/ 30 \%$ OK cleaned blends were both lower than 1 mill/10000 hours. These rates are considered low relative to common design fuels.

Pilot-scale testing of the MPC Watson baseline coal (Jader Illinois blend) and alternate coal (Island Creek Kentucky No. 11 coal) were initiated. Testing of the Watson coals 
Table 1.

FPTF Operating Conditions for Pilot-Scale Testing of PSO Coals

\begin{tabular}{|c|c|c|c|c|c|}
\hline Test \# & $\begin{array}{c}\text { Duration } \\
\text { (hrs) }\end{array}$ & $\begin{array}{c}\text { Firing Rate } \\
\text { (MBru) }\end{array}$ & $\begin{array}{c}\text { Avg Oper Temp } \\
\left({ }^{\circ} \mathrm{F}\right) \\
\end{array}$ & $\begin{array}{c}\text { \%Excess } \\
\text { Air }\end{array}$ & $\begin{array}{l}\text { \%Heat Flux } \\
\text { Recovery }\end{array}$ \\
\hline \multicolumn{6}{|c|}{$100 \%$ WYOMING } \\
\hline 1 & 12 & 3.6 & 2978 & 20 & 45 \\
\hline 2 & 12 & 3.4 & 2834 & 20 & 53 \\
\hline 3 & 12 & 3.2 & 2822 & 20 & 82 \\
\hline 4 & 12 & 3.3 & 2800 & 12.5 & 50 \\
\hline 5 & 12 & 3.3 & 2832 & 30 & 74 \\
\hline 6 & 12 & 3.3 & 2860 & 20 & $\mathrm{NA}$ \\
\hline \multicolumn{6}{|c|}{ 90\% WYOMING / 10\% OKLAHOMA } \\
\hline 1 & 12. & 3.3 & 2860 & 20 & 97 \\
\hline 2 & $1 i^{\prime}$ & 3.7 & 2940 & 20 & 82 \\
\hline 3 & 9 & 4.0 & 2970 & 20 & 0 \\
\hline 4 & 12 & 3.8 & 3033 & 12.5 & 50 \\
\hline 5 & 12 & 3.8 & 2900 & 30 & 59 \\
\hline 6 & 10 & 3.7 & 2952 & 20 & NA \\
\hline \multicolumn{6}{|c|}{ 70\% WYOMING / 30\% OKLAHOMA } \\
\hline 1 & 12 & 3.7 & 2945 & 20 & 0 \\
\hline 2 & 12 & 3.3 & 2837 & 20 & 15 \\
\hline 3 & 12 & 3.0 & 2760 & 20 & 82 \\
\hline 4 & 12 & 3.2 & 2795 & 12.5 & 17 \\
\hline 5 & 12 & 3.2 & 2816 & 30 & 0 \\
\hline 6 & 12 & 3.2 & 2797 & 20 & 15 \\
\hline \multicolumn{6}{|c|}{ 70\% WYOMING / 30\% OKLAHOMA (Cleaned) } \\
\hline 1 & 12 & 3.2 & 2821 & 20 & 97 \\
\hline 2 & 12 & 3.6 & 2911 & 20 & 95 \\
\hline 3 & 12 & 4.0 & 2984 & 20 & 51 \\
\hline
\end{tabular}




\section{Slagging Algorithm} Development

Task 4 - Utility Boiler Field Testing

\author{
Northern States Power \\ Company \\ King Unit 1
}

will be completed in July; data reduction and reporting are underway.

PSI Technology Company (PSIT), as a subcontractor to CE, is primarily responsible for developing the slagging algorithm. Data from laboratory, pilot, and full scale tests will be utilized to create the submodel relationships and, subsequently, to verify the predictions. Over the past quarter, PSIT has been developing recommendations for the slagging algorithm formulation.

The current vision of the slagging model has it predicting a relative sootblowing rate index (SRI). Six submodels will be utilized to calculate the SRI:

- Mineral Transformation into Flyash

- Gas and Particle Transport

- Boiler Performance

- Deposit Growth Rate

- Sootblower Effectiveness

- Deposit Thermal Properties

The model will be constructed to consider the effect of coal properties, boiler design, and boiler performance.

Development of the model to date has included discussions with various members of the CQE team, and visits to laboratory, pilot-scale, and full-scale test sites.

During the past quarter, full-scale combustion testing of the baseline coal blend was conducted at Northern States Power Company's King Unit No. 1. Data reduction, interpretation, and documentation continued for the tests performed at PSO's Northeastern Unit 4 and MPC's Watson Unit 4. A technical briefing was held at the Northeastern Plant in which the CQE test contractors presented preliminary findings of the field combustion tests and CQIM results to PSO personnel.

NSP's King 1 is the third of six test sites selected for utility boiler field testing under this program. It is located in Bayport, Minnesota, and consists of a Babcock and Wilcox (B\&W) 580-MWg, cyclone-fired, supercritical boiler which was commissioned in 1968 . The boiler nameplate rating is $3.873 \times 10^{6} \mathrm{lb} / \mathrm{hr}$ of steam flow at $1005^{\circ} \mathrm{F}$ superheat temperature and 3675 psi; design reheat is also $1005^{\circ} \mathrm{F}$, at 
$676 \mathrm{psi}$. The boiler is a single furnace configuration with two burner elevations on the front and rear furnace walls, with each wall having six cyclone burners arranged in a three wide by two high burner pattern.

Burn tests are being conducted to assess the coal quality impacts on boiler performance and emissions resulting from the burning of the typical, or baseline, coal blend and an alternate coal blend. The initial baseline coal was a blend of 70-percent Wyoming North Antelope coal, 20-percent Montana Westmoreland coal, and 10-percent petroleum coke. A likely candidate for the alternate coal is a blend of 90-percent Wyoming coal (Black Thunder or Antelope), 5percent Montana Westmoreland coal, and 5-percent petroleum coke. The lower percentage of petroleum coke would reduce the overall sulfur content of the blend, resulting in $\mathrm{SO}_{2}$ emissions close to the "compliance" level of $1.2 \mathrm{lbs} / \mathrm{MBtu}$. At the same time, the larger fraction of the western coal content (95 versus 90 percent) would decrease the heating value of the alternate blend. The combination of the two could result in increased opacity/reduced ESP collection efficiency, aggravated fouling or slagging, and possibly adverse effects upon combustion within the cyclone burners. Typical properties of the two coal blends are presented in Table 2.

Because King $l$ is base-loaded during the summer months, testing was not permitted during July and August. It was decided to split the testing of the two coals prior to and following the summer peak. Testing of the baseline coal occurred over the period May 13 through May 31, 1991. Because of previous project commitments and the need to fully clean the boiler prior to testing the alternate coal blend (this will ensure that boiler conditions are similar for both test blends), the alternate coal test series has been scheduled for November, 1991. Thus, this section summarizes the test conditions for the baseline coal.

Following a brief series of diagnostic tests, the baseline coal test burn was conducted according to the matrix shown as Table 3. In addition to a detailed emissions and performance characterization at full load, tests were performed at varying levels of load and excess air. Tests of specific interest to NSP were performed to examine in more detail the fouling and carbon burnout characteristics of the 
Table 2.

Typical As-Received Raw Coal Analyses (NSP King Baseline and Alternate Test Coals)

\begin{tabular}{|c|c|c|c|c|c|}
\hline & $\begin{array}{r}\text { North } \\
\text { Antelope } \\
\text { Wroming }\end{array}$ & $\begin{array}{l}\text { West- } \\
\text { moreland } \\
\text { Montand }\end{array}$ & $\begin{array}{r}\text { Petroleum } \\
\text { Coke }\end{array}$ & $\begin{array}{r}\text { Estimated } \\
70 / 20 / 10 \\
\text { Base Blend }\end{array}$ & $\begin{array}{l}\text { Estimated } \\
90 / 5 / 5 \\
\text { Alt. Blend }\end{array}$ \\
\hline \multicolumn{6}{|c|}{ PROXIMATE ANALIYSIS (WrX) } \\
\hline Tolal Moisture & 26.19 & 23.76 & 0.92 & 23.18 & 24.81 \\
\hline Ash & 5.18 & 9.87 & 0.29 & 5.63 & 5.17 \\
\hline Volatile Motter & 31.11 & 29.47 & 10.56 & 28.73 & 30.00 \\
\hline Fixed Carbon & 37.52 & 36.89 & 88.45 & 42.49 & 40.04 \\
\hline Heating Value (Btu/fb) & 8,845 & 8,683 & 15,105 & 9,439 & 9,150 \\
\hline \multicolumn{6}{|l|}{ Sulfur } \\
\hline Total $(W+\%)$ & 0.21 & 0.71 & 5.71 & 0.86 & 0.51 \\
\hline $\mathrm{SO}_{2}(\mathrm{Ib} / \mathrm{Mbtu})$ & 0.47 & 1.64 & 7.56 & 1.82 & 1.11 \\
\hline Ash (lb/MBtu) & 5.86 & 11.37 & 0.19 & 5.96 & 5.65 \\
\hline Hardgrove Grind (HGI) & 44 & 51 & 46 & 46 & 45 \\
\hline Chlorine $(W+\%)$ & 0.01 & 0.02 & $N / A$ & 0.01 & 0.01 \\
\hline \multicolumn{6}{|c|}{ ULTIMATE ANALYSIS (W+\%) } \\
\hline Corbon & 51.42 & 50.76 & 87.67 & 54.91 & 53.20 \\
\hline Hydrogon & 3.56 & 3.43 & 3.34 & 3.51 & 3.54 \\
\hline Nitrogen & 0.68 & 0.69 & 1.55 & 0.77 & 0.72 \\
\hline Sulfur & 0.21 & 0.71 & 5.71 & 0.86 & 0.51 \\
\hline Ash & 5.18 & 9.87 & 0.29 & 5.63 & 5.17 \\
\hline Oxygen & 12.86 & 10.77 & 0.59 & 11.22 & 12.14 \\
\hline \multicolumn{6}{|l|}{ ASH FUSIBHLITY ( F) } \\
\hline \multicolumn{6}{|l|}{ (Reducing/Oxidizing) } \\
\hline Initial Doiormotion & $2147 / 2194$ & $2091 / 2168$ & $2350 / 2675$ & & \\
\hline Sottoning & $2160 / 2214$ & $2117 / 2197$ & $2435 / 2700$ & & \\
\hline Homispherical & $2172 / 2233$ & $2141 / 2232$ & $2520 / 2700$ & & \\
\hline Fluid & $2210 / 2342$ & $2194 / 2302$ & $2600 / 2700$ & & \\
\hline \multicolumn{6}{|c|}{ ASH COMPOSIIION (W+\%) } \\
\hline $\mathrm{SiO}_{2}$ & 39.65 & 37.54 & & & \\
\hline $\mathrm{Al}_{2} \mathrm{O}_{3}$ & 18.30 & 17.38 & & & \\
\hline $\mathrm{F}_{\bullet_{2}} \mathrm{O}_{3}$ & 5.34 & 6.04 & & & \\
\hline $\mathrm{CaO}$ & 17.28 & 17.04 & & & \\
\hline $\mathrm{MgO}$ & 4.72 & 2.73 & & & \\
\hline $\mathrm{Na}_{2} \mathrm{O}$ & 1.35 & 2.63 & & & \\
\hline $\mathrm{K}_{2} \mathrm{O}$ & 0.59 & 0.83 & & & \\
\hline $\mathrm{TiO}_{2}$ & 1.25 & 0.69 & & & \\
\hline $\mathrm{P}_{2} \mathrm{O}_{3}$ & 1.15 & 0.40 & & & \\
\hline $\mathrm{SO}_{3}$ & 9.03 & 2.63 & & & \\
\hline
\end{tabular}




\section{Table 3.}

NSP King Unit 1 Test Matrix (Baseline Coal Blend)

\begin{tabular}{|c|c|c|c|c|}
\hline Test & $\begin{array}{c}\text { Load } \\
(\mathrm{MWg})\end{array}$ & $\mathrm{O}_{2}$ & Test Objective & Tests \\
\hline \multicolumn{5}{|c|}{ Baseline Coal $(70 / 20 / 10)$} \\
\hline A & 550 & Norm & Initial Full Load Characterization & $\mathrm{B}, \mathrm{C}, \mathrm{M}$ \\
\hline G & 600 & Norm & Characterization of Max Load Operation & $\mathrm{B}, \mathrm{C}^{\cdot}, \mathrm{M}^{*}, \mathrm{~F}^{\cdot}$ \\
\hline B & 550 & Reduced & $\begin{array}{l}\text { Characterize Full Load Operation at Low } \\
\mathrm{O}_{2}\end{array}$ & $\mathrm{~B}, \mathrm{C}^{\cdot}$ \\
\hline $\mathrm{H}^{\circ}$ & 550 & Norm & Special Fouling/Slagging Test(s) & $\mathrm{B}^{*}, \mathrm{C}^{\circ}, \mathrm{F}^{*}$ \\
\hline $\mathrm{C}$ & 425 & Norm & Characterize 3/4 Load Operation & $\mathrm{B}, \mathrm{C}, \mathrm{M}$ \\
\hline $\mathrm{E}$ & 425 & Reduced & $\begin{array}{l}\text { Characterize 3/4 Load Operation at Low } \\
\mathrm{O}_{2}\end{array}$ & $\mathrm{~B}, \mathrm{C}$ \\
\hline \multirow[t]{2}{*}{$\mathrm{F}$} & 550 & Norm & $\begin{array}{l}\text { Detailed Characterization of Full Load } \\
\text { Operation }\end{array}$ & $\mathrm{B}, \mathrm{C}, \mathrm{M}^{\circ}, \mathrm{F}, \mathrm{E}$ \\
\hline & 550 & Norm & Special Tests & $\mathrm{B}, \mathrm{C}^{*}, \mathrm{~F}^{\bullet}$ \\
\hline
\end{tabular}

\section{Notes:}

- Optional

B - Boiler monitoring (control room, gaseous, opacity, etc.)

C - Combustion performance (ash carbon or gas traverse)

M - Mill monitoring (fineness, vibration, rejects, etc.)

F - Furnace measurements (exit gas temp or slagging/fouling)

E - ESP measurements (V/I, loading, size distribution, resistivity, $\mathrm{SO}_{3}$ ) 
coal blend when operating the unit under particularly demanding operating conditions.

Baseline testing was interrupted and delayed early in the test series as a result of stack opacity problems with the original baseline test coal. It was thought that this may had been a result of a couple test coal shipments containing lower sulfur and sodium content than normal (although still within the fuel specification). Daytime peak load was reduced from $550 \mathrm{MW}$ to $480 \mathrm{MW}$ or less to maintain opacity within the 20 -percent limits. For a period of a couple days, the baseline coal was changed to a blend of $65 \%$ Wyoming/20\% Montana/15\% petroleum coke to increase $\mathrm{SO}_{2} / \mathrm{SO}_{3}$ levels to the ESP and reduce opacity. Following a new shipment of test coal, testing continued with the original 70/20/10 blend and opacity levels returned to acceptable levels; the 70/20/10 blend was used for the remainder of the baseline test program.

The tentative schedule for field testing the alternative coal at NSP King 1 and the baseline and alternative coals at the next field site - Alabama Power Company's Gaston Unit 5 is as follows:

- $\quad$ APCO Gaston 5 Set-up

- APCO Gaston 5 Diagnostics

- APCO Gaston 5 Baseline Coal

- $\quad$ NSP King 1 Boiler Outage

- NSP King 1 Alternate Coal

- APCO Gaston 5 Alt. Coal
Aug 12-17, 1991

Aug 19-30, 1991

Sep 16 - Oct 12, 1991

Sep 20-29, 1991

Oct 28 - Nov 20, 1991

Jan 28 - Feb 29, 1992
Task 5 - CQIM Completion and Development of CQE Specification
The primary objectives of this task are to:

- Improve and enhance the Coal Quality Impact Model (CQIM)

- Identify and assemble all models and data bases to be incorporated into the CQE

- Develop the specification for the CQE.

During the past quarter, efforts were directed at the basic functionality software needs/sources of the CQE, Beta testing of the Acid Rain Advisor (ARA), and definition and planning for algorithm development. 
Program Definition and Initial Software Development

Acid Rain Advisor

CQIM Enhancements and Algorithm Development
The objects required for the CQE were preliminarily established and initial efforts were made to define the applications for which CQE could be applied. Sixteen applications were identified (Figure 1) and detailed diagrams were constructed for some of the applications which outline the required module capabilities. This list of applications should be vietved as "preliminary" at this time; Black \& Veatch $(B \& V)$ will continue to refine these applications based on their own review, and comments received from other project participants.

Sources for an object data base management system (ODBMS) and other object oriented tools were also investigated. B\&V held discussions with Servio Corporation, Object Design, and Ontologic (ONTOS) to gather information on ODBMS's.

An iritial version of an object diagrammer was created which frovides a graphical means for depicting objects and their interactions during CQE design. This represented the first object oriented programming efforts for CQE and provides a means to develop initial CQE-specific $\mathrm{C}++$ and object oriented programming techniques.

The inicial version of the ARA was completed in early April and the program and a simple set of documentation were sent out to the following utilities for Beta testing:

- Iowa Electric Light \& Power Co.

- East Kentucky Power Cooperative

- Kentucky Utilities

- $\quad$ PSI Energy

- Southern Company Services

- Tennessee Valley Authority

- Wisconsin Public Service

Program modifications were made throughout the past quarter based on comments received from the above testers and B\&V's in-house review.

Work continued on developing heat balance algorithms and mill capacity correction routines for the ball tube mill model. A limited amount of data was collected by $B \& V$ from Riley Stoker; Southern Company Services and Electric Power Technologies were identified as sources for further data. 


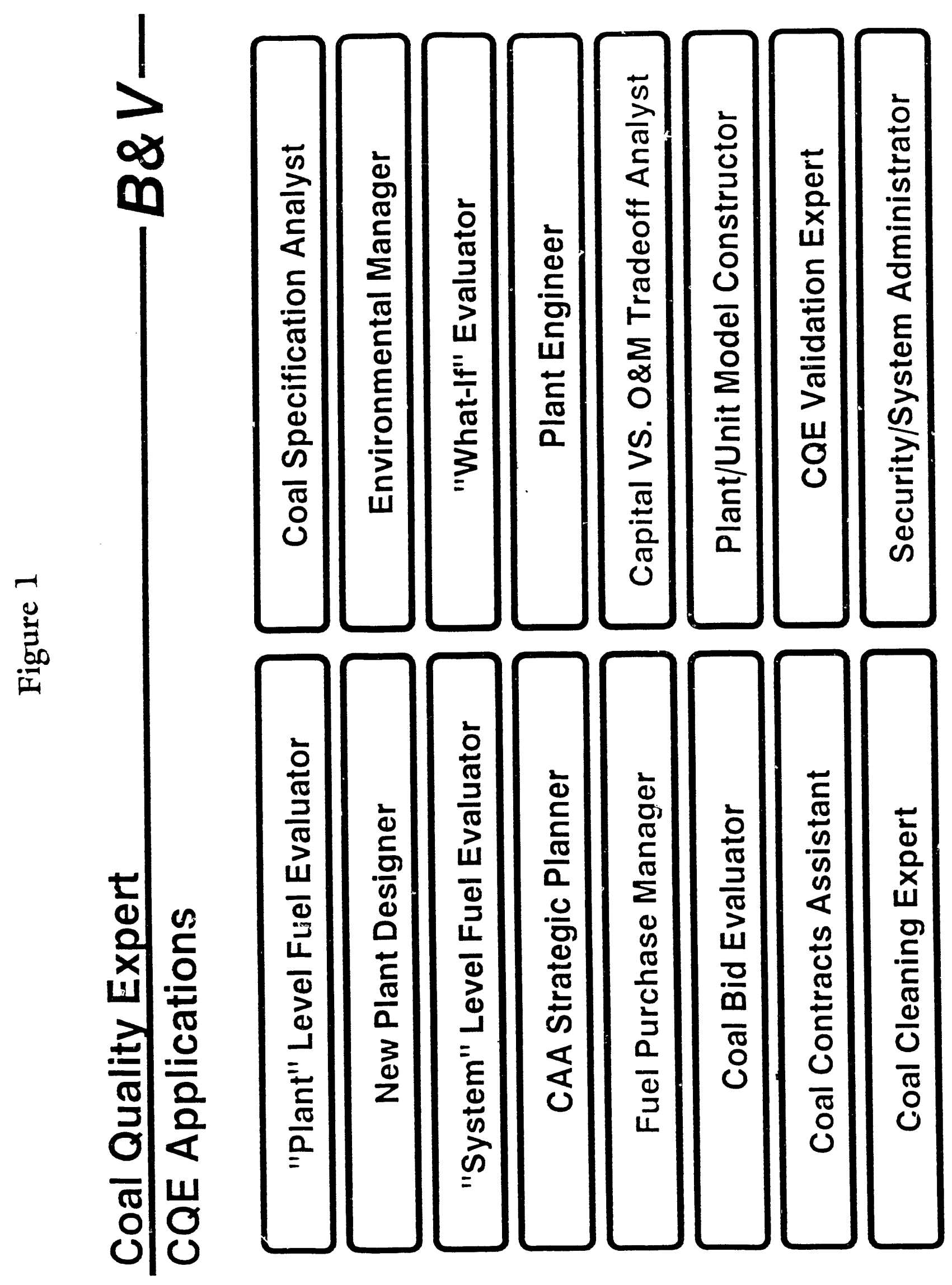


Responsible parties for each identified algorithm were appointed and a preliminary schedule was issued for development meetings for each algorithm/submodel. Identified algorithms/submodels to date include:

- Coal Purchase/Transport

- Twin Furnace

- Ball Mill

- Pulverizer Wear/Erosion

- Precipitator

- Landfill/Pond

- Coal Handleability

- CQE Executive Shell

- Acid Rain Advisor

- New Plant Design
- Steam Generator

- NO Formation

- Pulverizer

- Tube Failure/Erosion

- Wet Lime FGD

- Low Vol Coal Treat.

- NERC/GADS

- Fireside Advisor

- FGDCOST
PROJECT MEETINGS
The following major project meetings were held over the past quarter:

A technical briefing on field test and CQIM results was presented at PSO's Northeastern Station in Oologah, Oklahoma on May 10, 1991; copies of overheads were subsequently distributed to appropriate project participants.

A CQE technical review meeting was held at the University of North Dakota's Energy and Environmental Research Center in Grand Forks, North Dakota on June 4-6, 1991. 

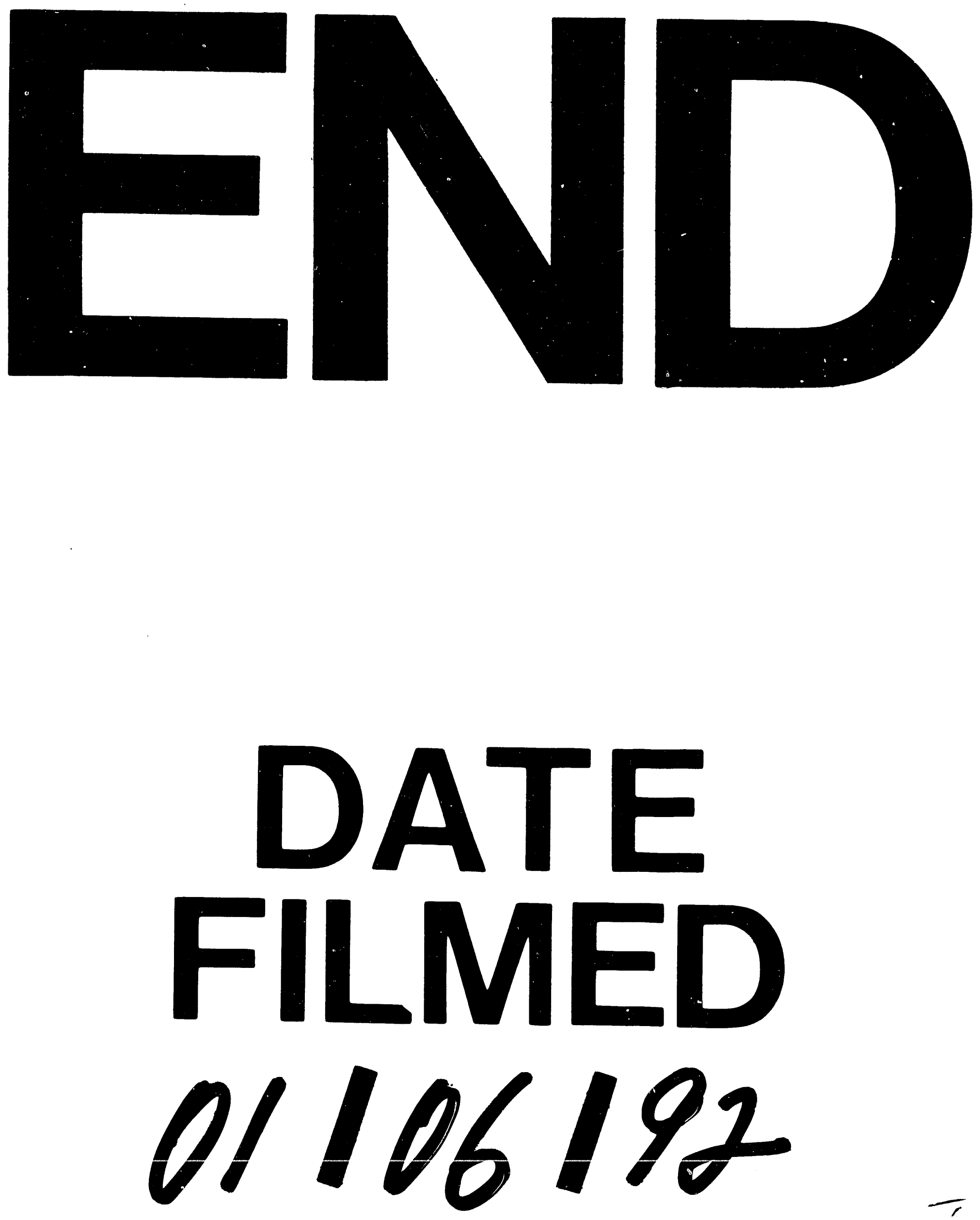
